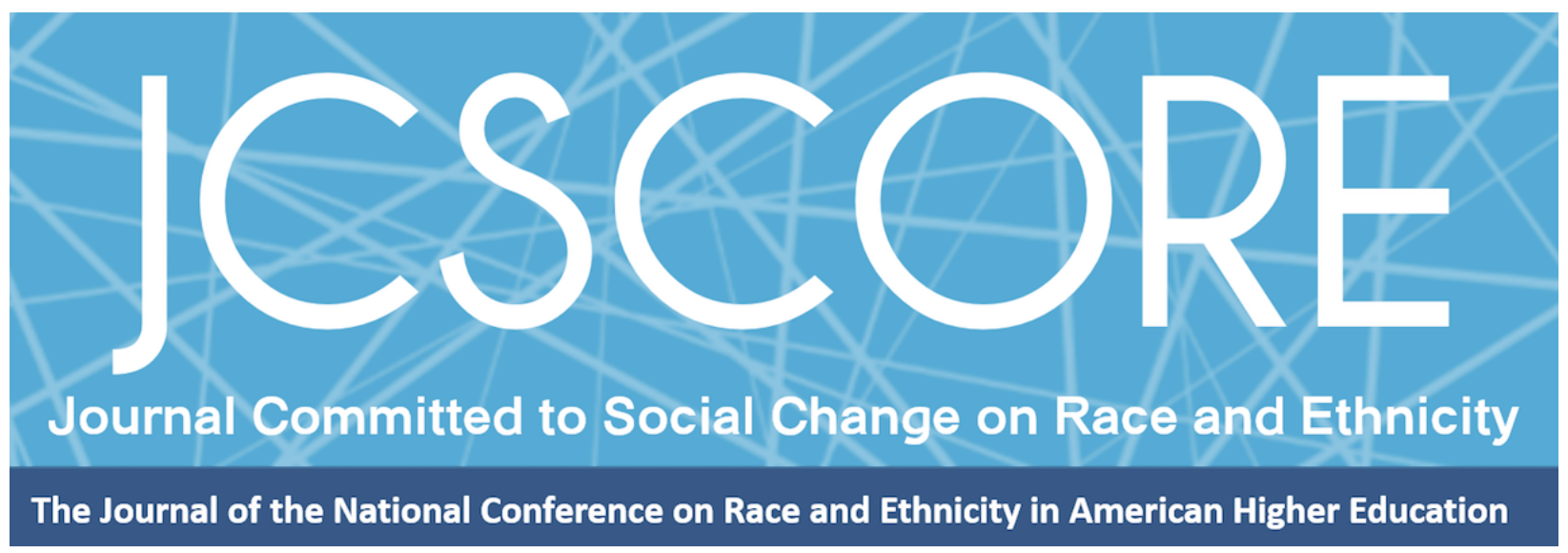

\title{
A STARTING POINT FOR DISABILITY JUSTICE IN LEGAL EDUCATION
}

\author{
Christina Payne-Tsoupros \\ University of the District of Columbia David A. Clarke School of Law
}

Journal Committed to Social Change on Race and Ethnicity

Volume 6, Issue 1 | 2020

\section{Copyright and Open Access}

(c) 2020 Christina Payne-Tsoupros

\section{(c) (i) (2) (2)}

This work is licensed under a Creative Commons Attribution-NonCommercial-ShareAlike 4.0 International License. Permission of the authors is required for distribution and for all derivative works, including compilations and translations. Quoting small sections of text is allowed as long as there is appropriate attribution and the article is used for non-commercial purposes.

The Journal Committed to Social Change on Race and Ethnicity (ISSN 2642-2387) is published by the National Conference on Race and Ethnicity (NCORE), a production of the University of Oklahoma, in partnership with the University of Oklahoma Libraries. 


\title{
A Starting Point for Disability Justice in Legal Education
}

\author{
Christina Payne-Tsoupros \\ University of the District of Columbia David A. Clarke School of Law
}

\begin{abstract}
This article explores how a disability justice framework would provide greater access to law school and therefore the legal profession for disabled students of color; specifically, disabled Black, Indigenous, and Latinx students. Using DisCrit principles formulated by Subini Annamma, David Connor, and Beth Ferri (2013), this article provides suggestions for incorporating a disability justice lens to legal education. In doing so, this article specifically recognizes the work of three disability justice activist-attorney-scholars, Lydia X.Z. Brown, Talila "TL" Lewis, and Katherine Pérez, and considers lessons from their advocacy and leadership that can apply in the law school setting.
\end{abstract}

This article explores how a disability justice framework would provide greater access to law school and, therefore, the legal profession for disabled students of color, particularly, disabled Black, Indigenous, and Latinx students. This article begins by describing legal education, including the laws governing disability accommodations in higher education - the Americans with Disabilities Act (ADA) (1990) and Section 504 of the Rehabilitation Act of 1973 (Section 504). After situating Critical Race Theory (CRT) and the Disability Critical Race Theory (DisCrit) framework formulated by Subini Annamma, David Connor, and Beth Ferri (2013) in their histories in critical legal studies,

\footnotetext{
Sincere thanks and gratitude to Talila "TL" Lewis and Katherine Pérez for their review and critique of an earlier draft of this article. I am humbled by and grateful for their thoughtful and educating comments. Thank you to participants at the 2019 Institute for Law Teaching and Learning Summer Conference and faculty scholarship rounds at the University of the District of Columbia David A. Clarke School of Law as well as to participants at the 2019 Association of Academic Support Educators Bi-Annual Diversity Conference, for stimulating discussion and thoughtful comments about the ideas presented in this article. Thank you also to the 2018-2019 student editors of the University of the District of Columbia Law Review and their faculty advisor, Marcy Karin, for their Disability Rights Law Symposium, which introduced me to some of the disability justice scholar-advocates highlighted in this piece. All errors are my own.
} 
Journal Committed to Social Change on Race and Ethnicity | Volume 6, Issue 1 | 2020

this article suggests considerations for using DisCrit to incorporate a disability justice lens in the law school setting. This section specifically recognizes the work of three disability justice activist-attorney-scholars, Lydia X.Z. Brown, Talila "TL" Lewis, and Katherine Pérez, and highlights the lessons from their advocacy and leadership that can apply to the law school setting. Then, this article concludes with a brief discussion of related issues that warrant consideration, including: questioning the structure of the ADA and 504 laws; stigma and discrimination around disability; and the licensing requirements to practice law. With respect to language, this article uses "person-first" (i.e., "students of color" or "students with disabilities") and "identity-first" (i.e., "disabled students") language interchangeably in an effort to be the most inclusive of the large numbers of students who may be affected by racism and ableism.

\section{Where Is Legal Education?}

This section provides an overview of legal education, including an explanation of the self-disclosure process for disabled students and the culture prevalent in many law schools that can contribute to student nondisclosure and under-disclosure of disabilities.

\section{Traditional Law School Environment}

Law school is typically taught in a three-year full-time program, and a number of institutions have four-year part-time/evening programs (Association of American Law Schools, n.d.). According to the annual disclosures required by the American Bar Association (ABA, 2019c), which is the accrediting body for law schools, $54 \%$ of the first-year law students matriculating in fall 2019 identified as women and 31\% identified as racial minorities. Of those who identified as being a person of color, $40 \%$ identified as 
Journal Committed to Social Change on Race and Ethnicity | Volume 6, Issue 1 | 2020

men and $60 \%$ identified as women. There are currently no data capturing the numbers of disabled law students matriculating each year.

Data from the U.S. Department of Education (2019) shows that $11.9 \%$ of students in post-baccalaureate programs self-reported a disability in 2015-2016, but that number is not disaggregated by graduate program. A 2011 report from the American Bar Association Commission on Mental and Physical Disability Law reported that $6.87 \%$ of ABA members self-identified as having a disability (ABA, 2011, p. 6). In its 2019 annual Profile of the Legal Profession, the ABA stated, "No reliable statistics exist on the total number of lawyers with disabilities in all parts of the legal profession"(ABA, 2019a, p.13).

Law school is a high-pressure, high-stakes environment. As described by several scholars, including Olympia Duhart (2015) and Wendy F. Hensel (2008), the culture of many law schools is marked by extreme competitiveness that is exacerbated when students compete against each other on a forced curve, all competing for the same one or two "A" grades (Duhart, 2015; Hensel, 2008). Even in schools without this extreme cut-throat culture, sky-rocketing student debt and the retraction of the legal job market can also contribute to a high-pressure environment (Hensel, 2008). Further, students may have misperceptions of the governing law and the accommodations that disabled students are entitled to, thereby potentially feeding feelings of resentment toward students who do receive them (Foster, 2014).

\section{Law School Climate Contributes to Under-Disclosure of Disabilities}

In higher education, self-disclosure is required for eligible students to receive the accommodations to which they are entitled under the ADA and Section 504. 
Journal Committed to Social Change on Race and Ethnicity | Volume 6, Issue 1 | 2020

Accommodations theoretically/ideally increase access to a legal education for students with disabilities, thereby providing greater access to the bar and leading to a more inclusive profession. The process for obtaining accommodations can be burdensome and may subject disabled students to stigma and discrimination from peers and others; however, there are also risks for students who do not disclose. In addition to not receiving the accommodations to which they are legally entitled, students may experience failure and frustration as well as feelings of isolation. Students' considerations regarding disclosure may vary across individuals and across populations of students. For example, as explored below, students with upper-middle class white privilege are taught to expect or demand things to which they feel entitled (Liu et al., 2007). Poor Black, Indigenous, and Latinx students are generally not taught and socialized in the same way.

\section{Americans with Disabilities Act and Section 504 of the Rehabilitation Act}

The primary laws that govern accommodations in higher education are (1) Titles II and III of the ADA, which applies to state-funded and private programs, respectively, including colleges and universities; and (2) Section 504, which applies to postsecondary institutions that receive federal funds, whether they are public or private. Law schools fall within the scope of Section 504 because virtually all law schools receive federal financial assistance in the form of scholarship support. For law schools that are part of a larger university, if the university receives federal funds, even if the law school does not, then the law school also falls within the scope of Section 504 (29 U.S.C. § 794(b); see also Rothstein, 2014, p. 529). 
Journal Committed to Social Change on Race and Ethnicity | Volume 6, Issue 1 | 2020

The standards under Title II of the ADA and Section 504 are essentially the same, and they are intended to be read consistently (Rothstein, 2014, pp. 529-530). The statutes prohibit discrimination on the basis of disability for individuals with: (1) "a physical or mental impairment that substantially limits one or more major life activity;" (2) "a record of such an impairment;" or (3) "being regarded as having such an impairment" (29 U.S.C. § 794(9)(B); 42 U.S.C. § 12101(1)). The statutes entitle the student to protection from discrimination on the basis of disability and provide "reasonable accommodations" for access (42 U.S.C. § 12112(b)(5)(A); 34 C.F.R. §§ 104.3(1)(1), 104.12). The accommodation is not required if it is unduly burdensome and if it would require some fundamental alteration of the nature of the program. In addition, the individual with the disability needs to be otherwise qualified to carry out the essential requirements of the program (42 U.S.C. § 12112(a); 34 C.F.R. § 104.3(k)(3)).

\section{Process for Obtaining an Accommodation in Higher Education}

Each university has its own policies for requesting an accommodation. The process for obtaining an accommodation in higher education requires documentation by an appropriate professional, which includes diagnosis of the student's disability and supporting information setting forth how the student's disability affects a major life activity. Designated personnel at the law school or university (often as part of a disability office) review the documentation in light of the essential requirements of the program and make an individualized determination of the appropriate auxiliary aids and services or modifications of policies and practices. Types of accommodations commonly granted in law school can include additional time on exams, a distraction-free exam environment, use of a computer in class or on an exam, emotional support animals, 
Journal Committed to Social Change on Race and Ethnicity | Volume 6, Issue 1 | 2020

digital or audio textbooks, note-takers, sign language interpreters, enlarged fonts, and preferred seating in the classroom. Katherine Macfarlane (2019), a disability law scholar and professor with disabilities, authored an essay in Ms. JD, highlighting the obstacles that students face with respect to accommodations, explaining that "obtaining an accommodation is itself an exhausting and time-consuming process" (para. 9).

\section{Reasons Students May Not Disclose Their Disabilities}

There are a variety of reasons why law students may choose not to disclose their disabilities. For example, in an essay entitled, "Making Peace with Testing Accommodations," Macfarlane (2018) wrote of the "dread" that she experienced as a law student due to the shame that she felt about receiving testing accommodations. Other reasons students may choose not to disclose may include lack of transparency and other barriers in the accommodations process. Similarly, the reasons students may not disclose their disabilities may differ depending on the identity(ies) of the particular students. There may be different implications for individuals from different socioeconomic classes, cultural backgrounds, generations, and disability type. Questions for legal faculty and administrators, as well as legal practitioners, to consider include:

- Are there different implications of disclosing a disability for students from different socioeconomic classes? Consider, for example, the recent "Varsity Blues" college admissions scandal. While many stories that made the popular press involved famous actors Laurie Loughlin and Felicity Huffman paying to falsify their children's SAT scores or to falsely pose as recruits for collegiate crew teams, this scandal also involved issues of individuals faking a disability to receive accommodations (Jaschik, 2019). In some ways, this plays into a common image many people already have - wealthy, white, non-disabled 
students at elite schools taking every advantage to cheat the system for their own benefit. It also bears questioning the effect this image may have on students outside of this particular socioeconomic group (smith, 2019). Are students now more reluctant to disclose their disabilities for fear (real and/or perceived) of being accused of faking?

- Are there different implications of disclosing a disability for students from different cultural backgrounds? Upper-middle-class white people are socialized to demand things due to a "sense of entitlement," and they teach their children to use "strategies of influence" in interactions with school institutions (Calarco, 2018; Lareau, 2011). In contrast, poor Black, Indigenous, and Latinx people typically do not carry the same entitlements and expectations of people and institutions of power (Weis, Cipollone, \& Jenkins, 2014). These differences contribute to differences in student approaches and expectations toward accommodations.

- Are there different implications of disclosing a disability for students from different generations? Many law school students are millennials (born between 1981 and 1996) and Generation Z (born from 1997 onward) (Dimock, 2019). Millennials and Generation Z, as well as younger members of Generation X (born between 1965 and 1980) (Dimock, 2019), attended school after the passage of the Individuals with Disabilities Improvement Education Act of 2004 (IDEA). As special education law has continued to develop, children in special education and general education had more opportunities to interact with each other than previous generations did, in part due to IDEA's requirement that children with disabilities be educated in the "least restrictive environment" (20 U.S.C. § 1412(a)(5)). It is worth considering whether the extent to which the implementation of the IDEA has affected today's law students' views of disability.

- Are there different implications of disclosing a disability for students with different disabilities? There may potentially be different implications or reactions to, for example, a Deaf student using an ASL interpreter for class lecture and a student with ADHD receiving time and a half on a time-pressured final examination. There can be different implications for students with physical or sensory disabilities versus students with non-apparent disabilities. 
Journal Committed to Social Change on Race and Ethnicity | Volume 6, Issue 1 | 2020

Populations of any group of students are not a monolith; so, these questions are not raised to generalize or stereotype students. Further, students come from a multitude of backgrounds where the categories listed above may overlap and intersect. This article does not seek to answer these questions raised above - rather, this article contends that it is important that questions like these are raised and acknowledged when considering learners in law school classrooms.

\section{Changes in Legal Education}

Changes that support disabled students accessing law school. As noted above, generations of children with disabilities who grew up before the passage of the IDEA (originally passed in 1975 as the Education for All Handicapped Children Act) were excluded from meaningful K-12 education. While the IDEA does not apply to law school or other institutions of higher education, the IDEA's mandate to provide "free appropriate public education" to children with disabilities from age three to high school graduation (or age 22, if that occurs later) (34 C.F.R. §§ 300.101(a); 102(b)(3)) means that disabled children now graduate from high school and have greater opportunities to access higher education (including law school) than disabled students of previous generations.

In recent years, there have been a few changes that increase access to law school for students. For example, more law schools are now accepting the GRE, which is considered more equitable than the LSAT, and the GRE is used in many graduate programs (Margiewicz, 2019). With respect to the LSAT itself, the Law School Admissions Council (LSAC), which develops and administers the LSAT, agreed, as part of a settlement with a blind test-taker in 2019 , to remove the logic games portion of the 
Journal Committed to Social Change on Race and Ethnicity | Volume 6, Issue 1 | 2020

exam because the games portion is inaccessible to blind students (Nyman Turkish PC, 2019). The LSAT has also recently gone completely digital (LSAC, n.d.).

Director Katherine Pérez and The Coelho Center for Disability Law, Policy and Innovation have created a first-of-its-kind fellowship program, The Coelho Center Law Fellowship Program, whose mission "is to train and mentor college students with disabilities to think about a path toward law school" (Loyola Law School, n.d.-c.). The program seeks to create "a strong pipeline of law students with disabilities who will go on to serve as attorneys, judges, public policy professionals, and politicians" (Loyola Law School, n.d.-c.). It is groundbreaking in its explicit commitment to disabled students of color.

While recognizing similar efforts toward increasing access to law school, it is important to note socioeconomic (and other) barriers to accessing legal education remain, which disproportionately affect disabled students of color, from inequities in K12 education to access to resources to prepare for the LSAT.

Changes in law school. While legal education retains its hallmarks of extreme competition, in recent years, many law schools have begun attempts to alleviate some of the pressures of this high-stakes culture. Significantly, as explained by Judith Welch Wegner (2018), academic support programs (ASP) have spread across law schools. While ASP varies from school-to-school, these programs have an explicit focus on student learning. Wegner reviews how ASP initially developed in the 1980 s as a way to foster racial diversity among schools and the profession and to support minority students. Programs have since broadened to include a wider range of students. 
Journal Committed to Social Change on Race and Ethnicity | Volume 6, Issue 1 | 2020

Other changes in law school include greater use of formative assessments and other opportunities to provide feedback to students throughout the semester (Duhart, 2015; Rothstein, 2014; Wegner, 2018; see also ABA, 2019b).

\section{Situating Critical Race Theory, DisCrit, and Disability Justice}

This section is not intended to be a full review of Critical Race Theory (CRT) or DisCrit. Instead, this section provides a brief overview of these fields to provide the proper context for the proposals that follow. For a comprehensive review, suggested readings include (1) Critical Race Theory: The Key Writings that Formed the Movement, edited by Kimberlé Crenshaw, Neil Gotanda, Gary Peller, and Kendall Thomas (1995); and (2) DisCrit: Disability Studies and Critical Race Theory in Education, edited by David J. Connor, Beth A. Ferri, and Subini A. Annamma (2016).

\section{Critical Race Theory's and DisCrit's Origins in Law}

In Kimberlé Crenshaw's 2011 article, "Twenty Years of Critical Race Theory: Looking Back to Move Forward," Crenshaw described the origins of CRT in the late 1980s in Critical Legal Studies. Critical Legal Studies emerged in law schools in the 1970s as an intellectual and political framework that interrogates the power dynamics embedded in law (see Tushnet, 1991, for a history of Critical Legal Studies). Crenshaw described the departure of Professor Derrick Bell from Harvard Law School in 1982 and the institution's failure to hire additional minority scholars, as well as the student activism that occurred in response. Students protested and created their own course with the "twin goals of recruiting minority professors ... and amplifying [the students'] deepening critique of American legal education" (Crenshaw, 2011, pp. 1278-1279). The students invited visiting scholars to teach the course each week. The aftermath of Bell's 
departure revealed deep institutional issues regarding the failure to integrate elite law school faculties. Several years later, several law professors of color, including Crenshaw, branched off from Critical Legal Studies due to the field's unwillingness to engage in race. CRT soon emerged as a "race intervention in a critical space" (Crenshaw, 2011, p. 1288).

The DisCrit framework explicitly builds on CRT and Crenshaw's (1989) conceptualization of intersectionality to analyze "why the location of being both a person of color and a person labeled with a dis/ability is qualitatively different for students of color than White students with a dis/ability" (Annamma et al., 2013, p. 5). The 2013 article by Subini Annamma, David Connor, and Beth Ferri, "Dis/ability Critical Race Studies (DisCrit): Theorizing at the Intersections of Race and Dis/ability," ushered in a new theoretical framework, Dis/ability Critical Race Studies or DisCrit. Annamma developed the term "DisCrit" "to render the links between perceptions of race and dis/ability more visible" (Annamma et al., 2016, p. 3). Annamma, Connor, and Ferri (2013) set forth seven tenets of DisCrit "to operationalize what kinds of specific questions and issues can be illuminated from a DisCrit approach" (pp. 11-18). ${ }^{1}$ In its

\footnotetext{
${ }^{1}$ The DisCrit tenets are:
}

1. DisCrit focuses on ways that the forces of racism and ableism circulate interdependently, often in neutralized and invisible ways, to uphold notions of normalcy.

2. DisCrit values multidimensional identities and troubles singular notions of identity such as race or dis/ability or class or gender or sexuality, and so on.

3. DisCrit emphasizes the social constructions of race and ability and yet recognizes the material and psychological impacts of being labeled as raced or dis/abled, which sets one outside of the western cultural norms.

4. DisCrit privileges voices of marginalized populations, traditionally not acknowledged within research.

5. DisCrit considers legal and historical aspects of dis/ability and race and how both have been used separately and together to deny the rights of some citizens.

6. DisCrit recognizes Whiteness and Ability as Property and that gains for people labeled with dis/abilities have largely been made as the result of interest convergence of White, middle-class citizens.

7. DisCrit requires activism and supports of all forms of resistance. (Annamma et al., 2013, p. 11) 
Journal Committed to Social Change on Race and Ethnicity | Volume 6, Issue 1 | 2020

initial formulization, DisCrit was positioned in the field of education, but is now expanding to other disciplines. ${ }^{2}$

\section{Disability Justice}

While academia is only recently beginning to challenge itself with DisCrit, scholar-activists have long been learning and practicing DisCrit tenets and disability justice (Annamma et al., 2016, pp. 1-2). The disability justice movement emerged in response to the failure of the disability rights and disability studies fields to account for "other forms of oppression and the ways in which privilege is leveraged at differing times and for various purposes" (Berne, 2015, p. 2). Patty Berne, author of a "working draft" of disability justice (2015), identified 2005 as the point in time in which she and Mia Mingus, Stacey Milberne, Leroy Moore, Eli Clare, and Sebastian Margaret began the discussions of a "second wave" of disability rights that culminated in articulating the disability justice framework (p. 2).

One of the hallmarks of the disability justice movement is "the leadership of disabled people of color and of queer and gender non-conforming disabled people" (Berne, 2015, p. 2). Lydia X.Z. Brown (2018), disability justice scholar-advocate, organizer, and attorney, explained disability justice as follows: "Disability justice is inherently intersectional, and understands our work as intricately connected with all movements for liberation and justice, because disability is implicated in every form of oppression" (para. 11).

\footnotetext{
${ }^{2}$ A second DisCrit book edited by Annamma, Ferri, and Connor - DisCrit Expanded: Inquiries, Reverberations \& Ruptures - is in development and expected to be published in 2020. This author is expected to have a co-authored chapter in the new DisCrit volume.
} 
Journal Committed to Social Change on Race and Ethnicity | Volume 6, Issue 1 | 2020

\section{Disability Justice in Legal Education: First Steps}

This section considers how the DisCrit framework can be used to apply principles of disability justice in legal education. In particular, the sections below seek to feature the work of Lydia X.Z. Brown, Talila "TL" Lewis, and Katherine Pérez, attorneys and disability justice scholar-activists. Consistent with the principles of DisCrit and disability justice, this author seeks to use this article as an opportunity to highlight the experiences and expertise of women, trans, non-binary, queer disabled attorneys of color.

\section{Incorporate a Critical Race Lens to Disability Legal Studies}

In her 2011 article, Arlene S. Kanter called for law schools to embrace a Disability Legal Studies framework. Like other critical law fields, Disability Legal Studies interrogates the legal system's role in the construction of disability. Katherine Pérez (2019) pushes this formulation, stating disability studies is currently undergoing a critique for its "failure to take race into account," as scholar-activists "have worked to recenter disabled people of color in the disability rights movement" (paras. 11-12). Pérez, the first Director of The Coelho Center for Disability, Law, Policy and Innovation, is the co-founder of The National Coalition for Latinx with Disabilities (CNLD), a doctoral candidate in Disabilities Studies at the University of Illinois at Chicago, and a visiting professor of law at Loyola Law School (Loyola Law School, n.d.-a.). Pérez (2019) explicitly states that, in the context of immigration law, "disability and race, cannot be considered separately" (para. 14). Moreover, consistent with the DisCrit tenet of privileging perspectives of marginalized populations (Annamma et al., 2013), Pérez 
Journal Committed to Social Change on Race and Ethnicity | Volume 6, Issue 1 | 2020

(2019) advocates using the law "in coordination with grassroots disability activism to effect social change for people with disabilities" (para. 1).

Talila "TL" Lewis is a community lawyer and consultant who works in the disability justice space. Lewis is the co-founder and volunteer director of the organization, Helping Educate to Advance the Rights of Deaf Communities (HEARD) (HEARD, n.d.; see also Lewis, n.d.). Lewis developed the following working definition of "ableism":

A system that places value on people's bodies and minds based on societally constructed ideas of normalcy, intelligence, excellence and productivity. These constructed ideas are deeply rooted in anti-Blackness, eugenics, colonialism and capitalism. This form of systemic oppression leads to people and society determining who is valuable and worthy based on a person's appearance and/or their ability to satisfactorily [re]produce, excel and "behave." You do not have to be disabled to experience ableism. (Lewis, 2020, image)

Lewis' definition positions anti-Black racism as one of the very foundations of ableism and embodies DisCrit tenets by naming the interdependence of racism and ableism (Annamma et al., 2013). Consistent with DisCrit, Lewis' definition also specifically names how the social construction of ability depends on anti-Black racism.

Pérez's and Lewis' scholarship creates a "race intervention" in disability studies and Disability Legal Studies, much like CRT created a "race intervention" in Critical Legal Studies (Crenshaw, 2011, p. 1288). Using immigration law as an example, in "A Critical Race and Disability Legal Studies Approach to Immigration Law and Policy," Pérez (2019) calls for the integration of disability legal studies and DisCrit into legal studies generally. Similarly, in Lewis' (2019) article, “Trump's Rule Attacking Disabled and Low-Income Migrants Has Violent History," Lewis illustrates the connections 
Journal Committed to Social Change on Race and Ethnicity | Volume 6, Issue 1 | 2020

between racism and ableism in a critique of the Trump administration's final public charge rule.

To apply some of Pérez's and Lewis' concepts in legal education, law teachers can question their own and their institution's practices with respect to race and disability.

Initia ${ }^{\beta}$ questions can include:

- How is the study of race and disability positioned in the curriculum? In clinic and other experiential learning opportunities - are students meeting clients with disabilities? What sort of training and reflection opportunities are provided to students to help them recognize and appreciate the diversity of lived experiences among clients with disabilities and to recognize the power differences in attorneyclient relationships? In non-clinical courses, how are racism and ableism addressed?

- What topics are considered disability topics? For example, immigration issues and the prison industrial complex typically are approached through a racial lens and are not usually taught or thought of as disability issues.

- Most law schools have chapters of the Black Law Students Association, Latinx Law Students Association, OUTLaw, a disability-affiliated law school student group, as well as others. To what extent are these groups siloed, rather than working in concert? What sort of institutional power do these student groups have?

- To what extent are people of color with disabilities invited as guest lecturers? Are these speakers invited to speak "only" on race and/or disability issues? To what extent are they invited to speak on the breadth and depth of issues within their expertise?

${ }^{3}$ These questions (and those posed later in the article) are intended as initial considerations and starting points for the legal education field. 
Journal Committed to Social Change on Race and Ethnicity | Volume 6, Issue 1 | 2020

\section{Provide Funding and Structural Support}

Providing funding and other forms of structural support for students with disabilities and students of color would increase access to legal education. Pérez is driven by disability justice principles of centering disabled people of color and uses an intersectional approach in running The Coelho Center Law Fellowship Program that creates a pipeline of future disabled law students. The Coelho Center explicitly encourages diverse candidates to apply to the program:

The Coelho Center for Disability Law, Policy and Innovation has a strong commitment to diversity as a core value. As such, we encourage applicants from a broad range of backgrounds with identities intersecting with disability including race, gender, sexual orientation, and immigration status. Applicants from low income backgrounds and applicants who have been involved in the criminal justice system are encouraged to apply. (Loyola Law School, n.d.-b.)

Pérez, as a recruiting strategy for the fellowship program, specifically reaches out to community colleges and other institutions with higher percentages of students of color to attract more diverse applicants to the fellowship program.

Lydia X.Z. Brown, who currently serves as policy counsel at the Center for Democracy \& Technology and an adjunct lecturer in disability studies at Georgetown University's Department of English (Center for Democracy \& Technology, n.d.), is one of the editors of the first ever anthology on autism and race, All the Weight of Our Dreams: On Living Racialized Autism (Brown et al., 2017). This anthology is a collection of art and writing by autistic people of color (Brown et al., 2017; see also Brown and the Autistic Women \& Nonbinary Network (AWN; 2020a) for a description of the contributing authors). Brown and AWN state:

We hope that this collection will not only speak sharply against our constant erasure and invisibility as (at least) doubly impacted, but will also provide solace 
Journal Committed to Social Change on Race and Ethnicity | Volume 6, Issue 1 | 2020

and familiarity for our own out there waiting for stories like theirs to be told. (2020b)

Brown, in partnership with AWN (of which they are founder and co-director), also recently launched the Fund for Community Reparations for Autistic People of Color's Interdependence, Survival, and Empowerment. With a mission to provide "direct support, mutual aid, and reparations by/for autistic people of color," the fund provides microgrants in the amount of $\$ 100$ to $\$ 500$ to autistic people of color (Brown \& AWN, 2020c, para. 1).

These efforts by Pérez and Brown demonstrate an explicit practice of the DisCrit tenets of valuing multidimensional identities, recognizing the material impacts on the social constructions of race and ability, and privileging traditionally marginalized perspectives (Annamma et al., 2013). Law teachers should consider how they and their institutions can apply some of these same strategies in legal education. Initial questions can include:

- What are the institution's feeder schools? Who has access to those schools, and who does not? What recruiting effort does the institution use to attract students of color and students of color with disabilities? What efforts are made to retain and provide ongoing support to these students?

- How can institutions provide direct financial support to students?

\section{Ask About the Creation of Disability}

In considering disability, Lewis (2019a) poses the following guiding question during a Longmore Lecture: "Ask, 'how is disability created?', as opposed to 'what causes disability?"' This framing shifts the question from individual students to the systemic barriers created by the institution and society. Law teachers can consider this 
Journal Committed to Social Change on Race and Ethnicity | Volume 6, Issue 1 | 2020

framing in their interactions with students to help identify and break down access barriers. Initial questions can include:

- Thinking beyond the accommodations/rights framework, what accommodations are provided without specific student request? Providing ASL interpreters at graduation and permitting the use of e-books, laptops, and other technology are just a few of the many types of accommodations that teachers and institutions can provide to everyone. Bearing in mind issues of under-disclosure of disability among law students, providing a broad base of accommodations to everyone can make legal education more accessible. This framing can question whether teachers should even require students to go through their institution's accommodations process to receive their accommodations.

- How can institutions alleviate barriers in the accommodations process itself? Students also may not know they potentially could qualify for accommodations (particularly if they did not receive them in their $\mathrm{K}-12$ or undergraduate education). In addition, while some students with disabilities received accommodations during their $\mathrm{K}-12$ education, the standard and the process is different in higher education, and students may not be aware of this.

- What are faculty attitudes toward disability? How do faculty members account for the way racism and ableism affect and compound the effects of each other?

- To what extent are people of color and people with disabilities represented on the law school faculty? A related area of inquiry is how a disability justice lens may affect law school faculty themselves, as faculty of color and faculty with disabilities remain underrepresented among law school faculty (e.g., Grigely, 2017).

The initial questions posed in this section overlap and interrelate, as do the tenets of DisCrit themselves. While the DisCrit framework makes clear how far legal education is from embracing the structural transformation and re-centering of power necessary for disability justice, it also highlights ways that law teachers and institutions can begin this important work. 
Journal Committed to Social Change on Race and Ethnicity | Volume 6, Issue 1 | 2020

\section{Areas of Future Research}

Future research should push beyond the initial efforts described here. When considering access to legal education and the profession, it is critical to think beyond specific individualized accommodations. Areas for further research and interrogation from a disability justice framework include questioning the structure of the ADA and Section 504 themselves. Unlike the "Child Find" requirements of the IDEA (20 U.S.C. § 1412(a)(3)), institutions of higher education have no obligation to identify and evaluate students with possible disabilities. In higher education, the obligation is on the students to disclose, if they wish to obtain accommodations. Areas of future research include questioning whether the law should be amended to incorporate a requirement similar to "Child Find" for institutions of higher education and considering the possible consequences of such an amendment.

Stigma is another area that merits additional research. Researchers in the substance use and mental health fields have long recognized that stigma and shame can be barriers for many to disclose and seek treatment (Bibelhausen et al., 2015; Organ et al., 2016). These fields are not wholly separate from disability; however, research from these areas can be helpful when considering disability more broadly in the law school context. Law schools have started taken some steps to counter the shame, discrimination, and stigma some students may face, including bringing speakers from lawyer assistance programs to campus, hosting alcohol-free events, and offering various wellness initiatives (Bibelhausen et al., 2015). Applying stigma-reducing strategies to the context of disability disclosure may be a way to leverage existing 
efforts in creating change in law school culture in a way to facilitate student disclosure and removal of barriers regarding disability more broadly.

The requirements to become licensed to practice law, including satisfying a jurisdiction's character and fitness requirements and passing the bar examination, are other areas that warrant further consideration. The character and fitness requirements typically necessitate the disclosure of a person's mental health treatment history (National Conference of Bar Examiners, n.d.-a), thereby discriminating against individuals with mental health disabilities and creating disincentives for law students to disclose. In addition, the bar examination is typically a two-day time pressured exam, comprised of essay questions and multiple-choice questions that purport to test a candidate's knowledge and the skills necessary to practice law (National Conference of Bar Examiners, n.d.-c.). Applying and studying for the bar examination is also expensive and time consuming, creating barriers to the profession for many students (Chong, 2018). ${ }^{4}$ Consequently, there are disparate bar passage rates of racial minority students compared to white peers (Chong, 2018). Overall, the structure of the bar examination is inconsistent with a disability justice framework, and this area is rife for future research.

Finally, it is important to acknowledge that while this article focused generally on race and disability, students are affected, often times multiply-so, by other systems of oppression, including heterosexism, transphobia, sexism, and others.

\footnotetext{
${ }^{4}$ For students preparing for the bar examination during the 2020 global COVID-19 pandemic, these barriers are becoming even harsher. While a handful of jurisdictions have offered alternative paths for licensure, the overwhelming majority of jurisdictions are (i) postponing the examination or (ii) continuing to hold an in-person exam with social distancing and other precautionary measures in place (see National Conference of Bar Examiners, n.d.-b.). The burdens of these changes-whether a postponed examination (and postponed licensure) or an in-person examination despite the pandemicdisproportionately affect marginalized students.
} 
Journal Committed to Social Change on Race and Ethnicity | Volume 6, Issue 1 | 2020

\section{Conclusion}

While this article highlights the particular work of Brown, Lewis, and Pérez, other disability justice activists who are disabled attorneys of color include Tiara Mercius, a recent law school graduate who writes about, among other things, medical racism experienced as a Black disabled woman (Mercius, n.d.; see also FourWheelWorkout, n.d.); and Victoria Rodríguez-Roldán, the Trans/Gender Non-Conforming Justice Project Director of the National LGBTQ Task Force (National LGBTQ Task Force, n.d.). Of course, in addition to the few attorneys named here, there are countless other scholar-activists who live and work disability justice in their daily lives whose expertise and experiences shape our understanding and practices of DisCrit and disability justice. According to Pérez (2019):

I believe that it is an iterative process in that theory informs praxis and vice versa. The current wave of activism of a new generation of disabled people (particularly disabled people of color) is informing the growth and future of a critical race and disability studies in legal academia. (para. 11)

As more disabled students enter law school, teachers and institutions need to recognize that the experiences of disabled students of color can be qualitatively different than that of disabled white students. Law schools have an obligation to interrogate their practices to determine how to best serve these students. 
Journal Committed to Social Change on Race and Ethnicity | Volume 6, Issue 1 | 2020

\section{References}

American Bar Association (ABA) Commission on Mental and Physical Disability Law. (2011). ABA disability statistics report. ABA.

https://www.americanbar.org/content/dam/aba/administrative/market_research/201 10314_aba_disability_statistics_report.pdf

American Bar Association (ABA). (2019a). ABA profile of the legal profession. ABA. https://www.americanbar.org/content/dam/aba/images/news/2019/08/ProfileOfProf ession-total-hi.pdf

American Bar Association (ABA). (2019b). Standards and rules for approval of law schools. §§ 314, 315. ABA.

https://www.americanbar.org/content/dam/aba/administrative/legal_education_and admissions_to_the_bar/standards/2019-2020/2019-2020-aba-standardschapter3.pdf

American Bar Association (ABA). (2019c). Various statistics on ABA approved law schools. ABA.

https://www.americanbar.org/groups/legal_education/resources/statistics/

Americans with Disabilities Act (ADA) of 1990, as amended, 42 U.S.C. $\S 12101$, et seq.

Annamma, S.A., Connor, D., \& Ferri, B. (2013). Dis/ability critical race studies (DisCrit):

Theorizing at the intersections of race and dis/ability. Journal of Race Ethnicity and Education, 16(1), 1-31.

Annamma, S.A., Connor, D., \& Ferri B. (2016). A truncated genealogy of DisCrit. In S.A. Annamma, D. Connor, \& B. Ferri (Eds.), DisCrit: Disability studies and critical race theory in education (pp. 55-70). Teachers College Press.

Association of American Law Schools. (n.d.). FAQ. Association of American Law Schools: https://www.aals.org/prospective-law-students/faqs/

Berne, P. (2015, June 10). Disability justice-A working draft. Sins Invalid. https://www.sinsinvalid.org/blog/disability-justice-a-working-draft-by-patty-berne

Bibelhausen, J., Bender, K.M., \& Barrett, R. (2015). Reducing the stigma: The deadly effect of untreated mental illness and new strategies for changing outcomes in law students. William Mitchell Law Review, 41(3), 918-947.

Brown, L.X.Z. (2018, April 23). The law won't get us freedom, but disability justice makes us better lawyers, better advocates, and better humans [Blog post]. PSJD Blog. https://blog.psjd.org/2018/04/23/the-law-wont-get-us-freedom-but-disabilityjustice-makes-us-better-lawyers-better-advocates-and-better-humans/

Brown, L.X.Z., Ashkenazy, E., \& Onaiwu, M.G. (Eds.). (2017). All the weight of our dreams: On living racialized autism. DragonBee Press.

Brown, L.X. Z., \& the Autistic Women \& Nonbinary Network. (2020a.). Contributors. Autism and Race: https://autismandrace.com/contributors/

Brown, L.X. Z., \& the Autistic Women \& Nonbinary Network. (2020b). All the weight of our dreams: on living racialized autism. Autism and Race. https://autismandrace.com/

Brown, L.X. Z., \& the Autistic Women \& Nonbinary Network. (2020c.). Autistic people of color fund. Autism and Race. https://autismandrace.com/autistic-people-of-colorfund/

Calarco, J.M. (2018). Negotiating opportunities: How the middle class secures advantages in schools. Oxford University Press. 
Journal Committed to Social Change on Race and Ethnicity | Volume 6, Issue 1 | 2020

Center for Democracy \& Technology (n.d.). Lydia X.Z. Brown. https://cdt.org/staff/lydiax-z-brown/

Chong, C.S.J. (2018). Battling biases: How can diverse students overcome test bias on the multistate bar examination. University of Maryland Law Journal on Race, Religion, Gender and Class, 18(1), 31-97.

Connor, D.J., Ferri, B.A, \& Annamma, S.A. (Eds.). (2016). DisCrit: Disability studies and critical race theory in education. Teachers College Press.

Crenshaw, K. (1989). Demarginalizing the intersection of race and sex: A Black feminist critique of antidiscrimination doctrine, feminist theory and antiracist politics. The University of Chicago Law Review, 140, 139-167.

Crenshaw, K.W. (2011). Twenty years of critical race theory: Looking back to move forward. Connecticut Law Review, 43(1), 1253-1352.

Crenshaw K., Gotanda, N., Peller, G., \& Thomas, K. (Eds.). (1995). Critical race theory: The key writings that formed the movement. The New Press.

Dimock, M. (2019, January 17). Defining generations: Where millennials end and generation $Z$ begins. Pew Research Center. https://www.pewresearch.org/facttank/2019/01/17/where-millennials-end-and-generation-z-begins/

Duhart, O. (2015). "It's not for a grade": The rewards and risks of low-risk assessment in the high-stakes law school classroom. Elon Law Review, 7, 491-526.

Foster, A.M. (2014). Reasonable accommodations on the bar exam: Leveling the playing field or providing an unfair advantage? Valparaiso University Law Review, 48, 661-693.

FourWheelWorkout aka 4WheelWomanist [@4WheelWorkOut]. (n.d.). Tweets [Twitter profile]. Retrieved December 2, 2019, from https://twitter.com/4WheelWorkOut

Grigely, J. (2017, June 27). The neglected demographic: Faculty members with disabilities. The Chronicle of Higher Education. https://www.chronicle.com/article/The-Neglected-Demographic-/240439

HEARD. (n.d.). Board members \& advisors. https://behearddc.org/about-us/boardmembers-advisors/

Hensel, W.F. (2008). The disability dilemma: A skeptical bench \& bar. University of Pittsburgh Law Review, 69, 637-656.

Individuals with Disabilities Education Improvement Act of 2004, 20 U.S.C. § 1400, et seq.

Individuals with Disabilities Education Improvement Act of 2004, 34 C.F.R. Part 300.

Jaschik, S. (2019, March14). First victims of admissions scandal? Inside Higher Ed. https://www.insidehighered.com/admissions/article/2019/03/14/advocatesstudents-learning-disabilities-fear-impact-admissions

Rehabilitation Act of 1973, as amended, 29 U.S.C. $\S 794$, et seq.

Kanter, A.S. (2011). The law: What's disability studies got to do with it or an introduction to disability legal studies. Columbia Human Rights Law Review, 42, 403-479.

Lareau, A. (2011) Unequal childhoods: Class, race, and family life ( $2^{\text {nd }}$ ed.). University of California Press.

Law School Admissions Council (LSAC). (n.d.). About the digital LSAT. LSAC https://www.lsac.org/lsat/taking-lsat/about-digital-lsat

Lewis, T.A. (n.d.). About me. https://www.talilalewis.com/about.html 
Journal Committed to Social Change on Race and Ethnicity | Volume 6, Issue 1 | 2020

Lewis, T.A. (2019a, March 5). Longmore lecture: Context, clarity \& grounding. https://www.talilalewis.com/blog/longmore-lecture-context-clarity-grounding

Lewis, T.A. (2019b, August 27). Trump's rule attacking disabled and low-income migrants has violent history. Truthout. https://truthout.org/articles/trumps-ruleattacking-disabled-and-low-income-migrants-has-violent-history/

Lewis, T.A. (2020, January 25). Ableism 2020: An updated definition. https://www.talilalewis.com/blog/ableism-2020-an-updated-definition

Liu, W.M., Pickett, T., \& Ivey, A. (2007). White middle-class privilege: Social class bias and implications for training and practice. Journal of Multicultural Counseling and Development, 35, 194-206.

Loyola Law School. (n.d.-a.). Director, Katherine Pérez.

https://www.lls.edu/coelhocenter/aboutus/director/

Loyola Law School. (n.d.-b.). Law fellows application information.

https://www.lls.edu/coelhocenter/lawfellowsprogram/application/

Loyola Law School. (n.d.-c.). The Coelho Center Law Fellowship Program.

https://www.lls.edu/coelhocenter/lawfellowsprogram/

Macfarlane, K. (2018, January 28). Making peace with testing accommodations. Ms. JD. https://ms-jd.org/blog/article/making-peace-with-testing-accommodations

Macfarlane, K. (2019, January 10). Testing accommodations are not a gift of extra time. Ms. JD. https://ms-jd.org/blog/article/testing-accommodations-are-not-a-gift-ofextra-time

Mercius, T.S. (n.d.). Four-wheel workout: Health and life in a wheelchair. https://fourwheelworkout.com/

Margiewicz, R. (2019, August 9.). The new role of the GRE in law school admissions. National Jurist. http://www.nationaljurist.com/prelaw/new-role-gre-law-schooladmissions

National Conference of Bar Examiners. (n.d.-a). Character and Fitness Investigations. http://www.ncbex.org/character-and-fitness

National Conference of Bar Examiners. (n.d.-b). NCBE COVID-19 Updates. http://www.ncbex.org/ncbe-covid-19-updates/

National Conference of Bar Examiners. (n.d.-c). Uniform Bar Examination. http://www.ncbex.org/exams/ube

National LGBTQ Task Force. (n.d.). Staff bio: Victoria Rodriguez-Roldan, J.D. https://www.thetaskforce.org/staff-bio-victoria-rodriguez-roldan-jd/

Nyman Turkish PC. (2019, October 7). Statement on the amicable resolution of Binno v. LSAC. Cision. https://www.prnewswire.com/news-releases/statement-on-theamicable-resolution-of-binno-v-lsac-lawsuit-300931402.html

Organ, J.M., Jaffe, D.B., \& Bender, K.M. (2016). Suffering in silence: The survey of law student well-being and the reluctance of law students to seek help for substance abuse and mental health concerns. Journal of Legal Education, 66, 116-155.

Pérez, K. (2019, February 2). A critical race and disability legal studies approach to immigration law and policy. UCLA Law Review. https://www.uclalawreview.org/acritical-race-and-disability-legal-studies-approach-to-immigration-law-and-policy/

Rothstein, L. (2014). Forty years of disability policy in legal education and the legal profession: What has changed and what are the new issues? American University Journal of Gender, Social Policy and the Law, 22, 519-650 
smith, s.e. (2019, March 27). Why the college admissions scandal threatens the disability community. Truthout. https://truthout.org/articles/why-the-collegeadmissions-scandal-threatens-the-disability-community/

Tushnet, M. (1991). Critical legal studies: A political history. Yale Law Journal, 100(5), 1515-1544.

U.S. Department of Education. (2019). Students with disabilities. National Center on Educational Statistics website: https://nces.ed.gov/fastfacts/display.asp?id=60

Wegner, J.W. (2018). Law school assessment in the context of accreditation: Critical questions, what we know and don't know, and what we should do next. Journal of Legal Education, 67(2), 412-461.

Weis, L., Cipollone, K., \& Jenkins, H. (2014). Class warfare: Class, race, and college admissions in top-tier secondary schools. University of Chicago Press. 